\title{
Grade Kambing Peranakan Ettawa pada Kondisi Wilayah yang Berbeda
}

\author{
Nur Rasminati \\ Program Studi Peternakan Fakultas Agroindustri, Universitas Mercu Buana Yogyakarta \\ Jl. Wates Km 10 Yogyakarta, 55753 \\ Email: nurrasminati@yahoo.co.id
}

\begin{abstract}
ABSTRAK
Penelitian ini bertujuan untuk mengetahui grade kambing Peranakan Ettawa (PE) yang dipelihara peternak di wilayah pesisir pantai dan wilayah pegunungan di kabupaten Kulon Progo. Responden diambil dari peternak kambing PE yang tinggal di desa Karangwuni mewakili daerah pesisir pantai dan di desa Sidomulyo mewakili daerah pegunungan, dengan jumlah kepemilikan ternak kambing berkisar antara 2-20 ekor. Metoda survei digunakan dalam penelitian, dengan pengambilan sampel responden secara sensus. Secara umum ukuran tubuh kambing PE di daerah pantai dan daerah pegunungan masih berada di bawah rata-rata standar. Beberapa ukuran tubuh kambing di daerah pegunungan lebih tinggi dibandingkan dengan pantai. Berdasarkan sifat kualitatif kambing PE di daerah pantai dan pegunungan masuk dalam grade B karena mempunyai ciri-ciri yang memenuhi standar dan imbangan serasi, tetapi berat dan ukuran tubuh dibawah rata-rata. Dapat disimpulkan bahwa ukuran-ukuran tubuh kambing PE di daerah pegunungan lebih tinggi dibandingkan dengan daerah pantai dengan grade kambing untuk kedua lokasi adalah grade B.
\end{abstract}

Keywords : Kambing Peranakan Ettawa, grade, daerah pantai, daerah pegunungan

\section{Grade of Ettawa Crossbred Goats at Different Areas}

\begin{abstract}
This study aimed to determine the grade of Ettawa crossbred goats reared in lowland (coastal) areas at Wates subdistrict and highland (mountainous) areas at Pengasih subdistrict, Kulonprogo. Respondents were drawn from goat breeders who live in the village Karangwuni for lowland areas and villages Sidomulyo for highland, with the ownership of goats ranged between 2 and 20. This study used survey method, and a sample of respondents was taken by the census methods. In general, body size of goats both in lowland and highland areas were below the average standard. Some body size of goats in highland areas were higher than lowland. Based on the qualitative characteristic of the goats in lowland and highland areas were included in grade $B$, it has characteristics that fulfil the standards and harmonious balance, but the weight and size of the body is below the average. It can be concluded that the body sizes goat in mountain areas is higher than in the beach with a grade goat for both locations is $B$.
\end{abstract}

Key words : Ettawa cossbred goats, grade, coastal area, mountains region 


\section{PENDAHULUAN}

Kabupaten Kulon Progo merupakan salah satu kabupaten di Propinsi Daerah Istimewa Yogyakarta (DIY) yang menjadi sumber bibit kambing Peranakan Ettawa (PE). Kambing PE banyak dipelihara oleh peternak di daerah pegunungan Menoreh, seperti Girimulyo, Samigaluh, Kokap dan sebagian Pengasih. Hal ini karena lingkungan yang mendukung untuk pengembangan kambing $\mathrm{PE}$, dan sumber daya alam khususnya ketersediaan pakan yang mencukupi untuk berkembangnya kambing PE. Namun, saat ini masyarakat yang tinggal di dataran rendah juga mulai mengembangkan budidaya ternak kambing, karena melihat prospek dan potensi ternak kambing PE yang sangat menjanjikan. Banyak masyarakat di pesisir pantai yang memelihara kambing, baik kambing lokal (kacangan) maupun kambing PE.

Pengembangan kambing PE di daerah pesisir merupakan alternatif yang perlu dikaji baik produksi maupun reproduksinya. Daerah pesisir menyimpan banyak sekali potensi pakan yang bisa digunakan untuk pengembangan kambing. Ketersediaan pakan dari tanaman pemecah angin dan tanaman pertanian yang mulai dikembangkan di daerah pantai sangat mendukung berkembangnya ternak kambing $\mathrm{PE}$ dan Bligon dengan berbagai variasi kualitas genetiknya.

Sistem penjualan Kambing PE dibedakan berdasarkan grade atau kelas, yaitu grade A, B, C, dan D. Untuk grade A menandakan bahwa kambing tersebut mempunyai kualitas super dibandingkan kelas B dan C, sedangkan untuk kambing yang masuk kelas D umumnya kambing berumur lebih dari satu tahun dan sudah afkir serta siap untuk dipotong. Grade kambing dapat mempengaruhi harga jual kambing tersebut. Berdasarkan harga jual di tingkat pedagang, kambing dengan grade $\mathrm{A}$ mempunyai harga jual lebih tinggi dibandingkan dengan ketiga grade lainnya. Penentuan grade kambing PE berdasarkan pada ciri-ciri karakteristik kualitatif maupun kuantitatif kedekatan dengan genetik kambing Ettawa. Kriteria yang digunakan adalah tinggi gumba, panjang badan, panjang dan bentuk telinga, profil muka, bentuk mandibula (rahang bawah), tanduk dan panjang bulu (Galih, 2010).

Pengetahuan mengenai penampilan ternak kambing PE bibit unggul menjadi suatu hal yang mutlak dalam rangka meningkatkan daya produksi ternak selanjutnya. Taksiran kemampuan seekor ternak dalam berproduksi dapat diketahui melalui pemanfaatan kriteria ukuran-ukuran tubuh. Peningkatan ukuran tubuh akan terjadi seiring dengan bertambahnya umur pada ternak. Setiadi et al. (1994), menyebutkan bahwa ketinggian tempat juga mempengaruhi ukuran tubuh ternak, kambing PE yang dipelihara di dataran tinggi memiliki ukuran tubuh yang lebih besar dibandingkan kambing PE yang dipelihara di dataran rendah. Berdasarkan pengukuran ukuran-ukuran tubuh yang pernah dilakukan terhadap kambing PE betina oleh Phalepi (2004), didapatkan persamaan dan perbedaan mengenai ukuranukuran tersebut dengan hasil pengamatan langsung di lapangan. Penelitian dilaksanakan dengan tujuan untuk mengetahui grade kambing PE yang dipelihara peternak di dua lokasi berbeda yaitu daerah pantai dan pegunungan.

\section{MATERI DAN METODE}

Materi yang digunakan dalam penelitian adalah ternak kambing pada berbagai fase yang dimiliki peternak di desa Karangwuni, Kecamatan Wates mewakili daerah pantai dan peternak di desa Sidomulyo, Kecamatan Pengasih mewakili daerah pegunungan.

Penelitian menggunakan metode survei dengan pengambilan responden secara purposive sampling. Variabel yang diukur adalah tinggi gumba, panjang badan, lingkar dada, panjang dan bentuk telinga, profil muka, warna bulu dan panjang bulu rewos. Data yang diperoleh dianalisis secara deskriptif. 
HASIL DAN PEMBAHASAN

\section{Ukuran-ukuran Tubuh Kambing Peranakan Ettawa}

Perubahan ukuran tubuh ternak dapat dijadikan sebagai indikator pertumbuhan ternak. Perubahan pada ukuran tubuh ternak menunjukkan apakah ternak mengalami pertumbuhan atau tidak. Peningkatan sedikit saja ukuran tubuh akan menyebabkan peningkatan yang proporsional dari bobot tubuh, karena bobot tubuh merupakan fungsi dari volume.

Ukuran-ukuran tubuh (data vital statistik) kambing PE di lokasi penelitian dapat dilihat pada Tabel 1. Ukuran-ukuran tubuh kambing PE untuk lingkar dada kambing PE di daerah pantai untuk fase indukan adalah 77,38 cm sedangkan di pegunungan 79,57 $\mathrm{cm}$. Menurut Pamungkas et al. (2009) standar lingkar dada untuk kambing PE betina dewasa adalah 80,1 cm. Lebih rendahnya hasil ini dikarenakan kondisi manajemen pemeliharaan dan kualitas genetik kambing PE yang dimiliki peternak masih sangat bervariasi.

Secara umum, ukuran-ukuran tubuh indukan kambing PE di daerah pantai untuk lingkar dada, dalam dada, lebar dada, panjang telinga, panjang tanduk, panjang bulu rewos dan bobot badan lebih rendah dibandingkan dengan kambing PE dari daerah pegunungan Menoreh. Sedangkan untuk tinggi gumba dan panjang badan kambing PE di daerah pantai lebih tinggi dibandingkan dengan daerah pegunungan. Hasil pengukuran lingkar dada di daerah pantai maupun pegunungan masih lebih rendah dibandingkan dengan standar mutu bibit untuk kambing PE betina dewasa (SNI, 2012) dan hasil penelitian Adiati dan Priyanto (2011). Rendahnya ukuran tubuh kambing PE di dua lokasi diduga karena mutu genetik kambing PE masih rendah dan manajemen pemberian pakan dalam kualitas maupun kuantitas masih belum kontinyu, yang berakibat pada rendahnya tingkat pertumbuhan ternak kambing.
Kambing PE jantan di daerah pantai mempunyai ukuran-ukuran tubuh untuk lingkar dada, dalam dada, panjang badan dan panjang bulu rewos yang lebih rendah dibandingkan dengan daerah pegunungan, sedangkan untuk lebar dada, panjang telinga, tinggi gumba dan bobot badan lebih tinggi dari rata-rata kambing $\mathrm{PE}$ di daerah pegunungan. Dibandingkan dengan standar kambing PE jantan dewasa menurut SNI tahun 2012 dan hasil penelitian Adiati dan Priyanto (2011), hasil ini juga masih lebih rendah.

Kambing dara di daerah pantai mempunyai panjang badan, lingkar dada, tinggi gumba, panjang telinga dan panjang bulu rewos yang lebih tinggi dibandingkan dengan rata-rata ukuran tubuh kambing dari daerah pegunungan, tetapi bobot badannya lebih rendah. Cempe betina di daerah pantai mempunyai lingkar dada, tinggi gumba, panjang badan dan bobot badan yang lebih tinggi dibandingkan dengan daerah pegunungan, sedangkan untuk ukuran tubuh yang lain lebih rendah.

Karakteristik kambing PE menurut Markel dan Subandryo (1997) adalah kuping menggantung ke bawah dengan panjang 18$19 \mathrm{~cm}$, tinggi badan antara $75-100 \mathrm{~cm}$, bobot jantan sekitar $40 \mathrm{~kg}$ dan betina sekitar $35 \mathrm{~kg}$. Kambing PE jantan berbulu di bagian atas dan bawah leher, rambut pundak dan paha belakang lebih lebat dan panjang. Kambing PE betina memiliki rambut panjang hanya pada bagian paha belakang. Warna rambut kambing PE terdiri atas kombinasi coklat sampai hitam atau abu-abu dan muka cembung (Hardjosubroto, 1994). Hasil penelitian hampir sama dengan hasil penelitian Markel dan Subandriyo (1997) serta Hardjosubroto (1994).

\section{Grade Kambing Peranakan Ettawa}

Kualitas kambing PE di lokasi penelitian oleh masyarakat lebih ditentukan oleh sifat kualitatif daripada sifat kuantitatif. Sifat kualitatif kambing PE lebih didasarkan pada kedekatan darah dengan kambing 
Tabel 1. Rata-rata ukuran tubuh kambing PE pada daerah pantai dan pegunungan

\begin{tabular}{lrrrrrrrr}
\hline \multirow{2}{*}{ Parameter } & \multicolumn{2}{c}{ Indukan } & \multicolumn{2}{c}{ Pejantan } & \multicolumn{2}{c}{ Dara } & \multicolumn{2}{c}{ Cempe } \\
\cline { 2 - 9 } & Pantai & Gunung & Pantai & Gunung & Pantai & Gunung & Pantai & Gunung \\
\hline Lingkar dada (cm) & 77,38 & 79,57 & 72,5 & 73 & 70,5 & 59,25 & 59 & 57,67 \\
Dalam dada (cm) & 14,08 & 16,92 & 14,5 & 15 & 11,5 & 12,25 & 12,5 & 13 \\
Lebar dada (cm) & 29,73 & 30,81 & 32 & 30,33 & 20 & 24,5 & 15,5 & 23,22 \\
Panj. telinga (cm) & 22,82 & 26,13 & 27,5 & 24,67 & 19 & 20,5 & 19,5 & 22,44 \\
Tinggi gumba (cm) & 74,62 & 72,38 & 80,5 & 71 & 65 & 54,75 & 57 & 55,89 \\
Panj. badan (cm) & 66,85 & 64,14 & 57 & 61 & 57,5 & 52 & 48 & 48,67 \\
Panj. tanduk (cm) & 7,27 & 8,87 & 8 & 6,33 & 6 & 3 & 3 & 2,17 \\
Bulu rewos (cm) & 11,64 & 14,53 & 12,5 & 14 & 12,5 & 11 & 7,5 & 9,33 \\
Berat badan (kg) & 40 & 41,46 & 39 & 34,67 & 27.5 & 29 & 17.5 & 16.22 \\
\hline
\end{tabular}

Tabel 2. Bangsa dan ciri-ciri karakteristik kambing PE di lokasi penelitian

\begin{tabular}{lcc}
\hline \multicolumn{1}{c}{ Parameter } & Pantai & Gunung \\
\hline Bangsa kambing (\%) & 16,67 & 50 \\
Peranakan Ettawa & 66,67 & 0 \\
Bligon & 16,67 & 50 \\
Peranakan Ettawa dan Bligon & & \\
Bentuk telinga (\%) & 72,22 & 100 \\
Melipat kedepan & 27,78 & 0 \\
Melipat kedalam & & \\
Warna bulu (\%) & 47,37 & 93,10 \\
Putih-hitam & 52,63 & 6,90 \\
Putih coklat & Melengkung & Melengkung \\
Profil muka & &
\end{tabular}

Ettawa. Menurut Sumadi (2001), sifat kualitatif meliputi bentuk umum, mata, rahang bawah, profil muka, bulu kaki belakang, tanduk, gelambir, telinga dan ambing.

Kambing PE, di tingkat peternak diseleksi dan dikatagorikan dalam 3 kelas atau grade kambing yakni grade $\mathrm{A}, \mathrm{B}$, dan C. Kambing PE kelas A dengan umur 2 tahun dapat mencapai tinggi punggung 90 $\mathrm{cm}$, dan panjang lebih dari $1 \mathrm{~m}$ dengan berat rata-rata kurang lebih $100 \mathrm{~kg}$ (Noer, 2007). Sedangkan untuk kambing PE ras Kaligesing, dibedakan menjadi 4 grade yaitu grade A, B, C dan D. Kelas A mempunyai ciri-ciri kepala melengkung atau cembung dan tidak berjambul, bibir bawah lebih kedepan, telinga menempel muka dengan lipatan kedepan sekitar $30 \mathrm{~cm}$, bergelambir, tanduk ke belakang melingkari telinga, warna bulu hitam penuh dari kepala sampai leher, panjang gumba sekitar $70 \mathrm{~cm}$, gembol atau rewos panjang dan tebal, lingkar dada lebar dan melengkung, ambing untuk betina dan testis untuk jantan mempunyai panjang yang sama (simetris), ekor besar seperti mawar dan lurus menyerupai tupai, tubuh besar dan sehat serta mempunyai kaki yang besar.

Hasil penelitian menunjukkan bahwa peternak di daerah pantai 66,67\% memelihara kambing Bligon, 16,67\% memelihara kambing PE serta 16,67\% memelihara kambing Bligon dan PE. Hal ini berbeda dengan peternak di daerah pegunungan yang 50\% memelihara kambing PE dan 50\% memelihara kambing PE dan Bligon. Peternak di daerah pantai sudah mulai meningkatkan kualitas genetik kambing yang dimiliki dengan cara 
mengawinkan indukan yang ada dengan pejantan PE unggul yang ada di wilayah Girimulyo maupun Jatimulyo, walaupun mereka harus membayar biaya kawin/inseminasi dengan jumlah yang cukup tinggi yaitu Rp. 500.000,- sampai Rp. 1.000.000,- untuk sekali kawin sampai bunting, tergantung kelas pejantan yang dipakai.

Berdasarkan ukuran-ukuran tubuh terutama tinggi gumba, panjang badan dan bobot badan serta ciri-ciri karakteristik kuantitatif dan kualitatif kambing PE, induk kambing PE, pejantan, dara dan cempe yang dipelihara peternak di daerah pantai dan pegunungan termasuk dalam grade $B$.

Ciri-ciri karakteristik kambing PE di daerah pantai dan pegunungan dapat dilihat pada Tabel 2. Walaupun termasuk dalam grade $\mathrm{B}$, namun dari beberapa ukuran tubuh induk kambing $\mathrm{PE}$ di daerah pegunungan lebih tinggi dibandingkan dengan di daerah pantai. Grade kambing PE induk di kedua lokasi penelitian ini belum memenuhi persyaratan grade A sehingga dikatagorikan dalam grade $\mathrm{B}$. Kambing PE yang termasuk dalam grade $\mathrm{B}$ mempunyai ciri-ciri memenuhi standar dan imbangan serasi tetapi berat dan ukuran dibawah rata-rata.

Pejantan kambing PE di daerah pantai dan daerah pegunungan termasuk dalam katagori B, karena walaupun mempunyai ciri-ciri yang memenuhi standar namun ukuran tubuh dan bobot badan masih berada di bawah rata-rata. Meskipun masuk dalam grade $B$, pejantan di daerah pantai mempunyai ukuran-ukuran tubuh yang lebih tinggi dibandingkan dengan pejantan di pegunungan Sidomulyo.

Hasil pengamatan menunjukkan bahwa warna tubuh dominan kambing PE adalah putih. Warna putih merupakan warna umum kambing PE yang didomestikasi dan pada kambing PE diketahui bahwa warna putih merupakan warna dominan terhadap hitam dan coklat. Hasil penelitian ini tidak berbeda jauh dari hasil sebelumnya yaitu warna tubuh dominan putih sebesar $>70 \%$ (Adiati dan Priyanto, 2011). Untuk warna bulu, 93,1\% peternak di wilayah pegunungan memilih kambing $\mathrm{PE}$ baik untuk cempe maupun dewasa yang berwarna kombinasi putih hitam, sisanya (6,9\%) kombinasi putih coklat sedang. Peternak di daerah pantai $47,37 \%$ mempunyai kambing PE berwarna bulu kombinasi putih hitam, sedangkan 52,63\% kombinasi putih coklat. Semakin penuh warna bulu hitam dari kepala sampai leher, semakin tinggi nilai ekonomisnya.

Kambing PE fase dara di daerah pantai dan daerah pegunungan mempunyai tinggi gumba $65 \mathrm{~cm}$ vs 54,75 cm; panjang badan $57,2 \mathrm{~cm}$ vs $52 \mathrm{~cm}$, bobot badan 27,5 kg vs $29 \mathrm{~kg}$, warna bulu di daerah pantai $50 \%$ kombinasi putih hitam dan 50\% kombinasi putih coklat, untuk daerah pegunungan $100 \%$ kombinasi putih hitam, panjang bulu rewos $12,5 \mathrm{~cm}$ vs $11 \mathrm{~cm}$ dan panjang telinga $19 \mathrm{~cm}$ vs 20,50 cm dengan bentuk telinga melipat kedepan baik untuk daerah pantai maupun pegunungan 100\% dan bentuk muka sedikit melengkung/ cembung masuk dalam katagori B.

Kambing PE fase cempe di daerah pantai dan daerah pegunungan mempunyai tinggi gumba $57 \mathrm{~cm}$ vs 55,89 cm; panjang badan $48 \mathrm{~cm}$ vs $48,67 \mathrm{~cm}$, bobot badan 17,5 $\mathrm{kg}$ vs 16,22 kg, warna bulu di daerah pantai dan daerah pegunungan 100\% kombinasi putih hitam, panjang bulu rewos $7,5 \mathrm{~cm}$ vs $9,3 \mathrm{~cm}$ dan panjang telinga $19,5 \mathrm{~cm}$ vs $22,44 \mathrm{~cm}$ dengan bentuk telinga 100\% melipat kedepan baik untuk daerah pantai maupun pegunungan dan bentuk muka sedikit melengkung / cembung masuk dalam katagori B.

\section{KESIMPULAN}

Dari hasil penelitian ini dapat disimpulkan bahwa ukuran-ukuran tubuh kambing PE induk di daerah pantai secara umum lebih rendah dibandingkan dengan daerah pegunungan, sebaliknya kambing PE jantan, dara dan cempe mempunyai ukuranukuran tubuh yang lebih tinggi. Kambing PE di daerah pantai dan daerah pegunungan sudah memenuhi persyaratan standar kambing PE bibit, namun ukuran-ukuran 
tubuh dan bobot badan masih di bawah ratarata sehingga dikatagorikan dalam grade $\mathrm{B}$ baik untuk betina dewasa, pejantan, dara dan cempe.

\section{DAFTAR PUSTAKA}

Adiati, U. dan D. Priyanto, 2011. Karakteristik Morfologi Kambing PE di Dua Lokasi Sumber Bibit. Seminar Nasional Teknologi Peternakan dan Veteriner 2011 (472-478)

Galih, 2010. Membedakan Kambing Peranakan Ettawa Berdasarkan Grade dan Visual. http://misteergalih.wordpress.com/2010/03/ 10/membedakan-kambing-peranakan ettawa-berdasarkan-grade-dan-visual/

Hardjosubroto, W. 1994. Aplikasi Pemuliabiakan Ternak di Lapangan. PT Gramedia Widya Sarana Indonesia, Jakarta.

Noer, A., 2007. Mari Beternak Kambing PE. http://www.banjar-jabar.go.id/rddesign. 2203-2009

Markel, R. C. dan Subandriyo. 1997. Sheep and Goat Production Handbook for Southeast Asia. 3rd ed. CV Ekha Putra, Bogor.
Phalepi, M. A. 2004. Performa kambing Peranakan Etawah (Studi kasus di peternakan Pusat Pertanian dan Pedesaan Swadaya Citarasa). Skripsi. Fakultas Peternakan. Institut Pertanian Bogor, Bogor.

Pamungkas, F. A., A. Batubara, M. Doloksaribu dan E. Sihite. 2009. Potensi Beberapa Plasma Nutfah Kambing Lokal Indonesia. Petunjuk Teknis. Pusat Penelitian dan Pengembangan Peternakan Badan Penelitian dan Pengembangan Pertanian Departemen Pertanian.

Setiadi, B. D. Priyanto., B. Sudaryanto dan tubuh pada domba persilangan domba Ekor Gemuk dengan pejantan Merino. Prosiding Seminar Nasional Sains dan Teknologi Peternakan. Pengolahan dan Hasil-hasil Penelitian. Buku kedua. Balai Penelitian Ternak. Pusat Penelitian dan Pengembangan Peternakan. Badan Penelitian dan Pengembangan Pertanian. Departemen Pertanian, Bogor : 457-462.

Sumadi, 2001. Estimasi dinamika populasi dan out put kambing Peranakan Etawah di Kabupaten Kulon Progo. Buletin Peternakan 25 (4): 161-171. 